\title{
APLIKASI REJIM PERSAMAAN MODEL GRAVITASI YANG TELAH DIRUBAH PADA KASUS DINAMIKA ARUS PERDAGANGAN INDONESIA DENGAN MITRA DAGANG DARI ASEAN
}

\author{
Barli Suryanta ${ }^{1}$
}

\begin{abstract}
The forthcoming 2015, ASEAN is being confident to implement ASEAN Free Trade (AFTA). The existence of AFTA is to outstrip trade liberalization due to augment trade volume significantly and transaction easing as well among the members of AFTA, mainly by inducing lower tariffs some certain commodities up to $0 \%$. This paper is conducted in order to examine on what prominent commodity of Indonesia compared to its counterparts namely Brunei, Malaysia, Philippines, Singapore and Thailand. These Indonesia counterparts are selected therefore they were the founding of ASEAN. Furthermore, this paper utilizes a modified Gravity Equation model. This model has an effort to estimate the significance of some parameters of variable from model equation. Thus, it can be detected that what are from these variables from a model equation being as a key determination factor to influence trading transactions. This paper also assesses the adjusted $R$-squared due to which Indonesia counterparts incur some vantage points as well as beneficial for Indonesia in terms of AFTA. The novelty contribution of this paper is to reveal the dynamics trade spillover between Indonesia some strategic sectors and its counterparts. By doing so, Indonesia is expected to be a dominant player in AFTA 2015 and taking some advantageous from AFTA into Indonesia account.
\end{abstract}

Keywords: AFTA 2015, a modified gravity equation model, analysis of data panel

JEL Classification: C33, C51, F15

1 Corresponding author: A Junior Lecturer and a Researcher at the School of Business and Management, Institut Teknologi Bandung (SBM ITB), Indonesia; tel. +62-22-2531923; email: barli.suryanta@sbm-itb.ac.id. I am indebted thanks to Dr. Deddy P. Koesrindartoto from SBM ITB, Dr. Andi M. Alfian Parewangi from the Bulletin of Monetary Economics and Banking, and Dr. Yoga Affandi from the DKM Bank of Indonesia. All these remarkable people already made some constructive remarks on my paper. Thanks to the God Almighty too. Every false upon my paper is mine. 


\section{PENDAHULUAN}

Dalam situasi perekonomian yang belum terintegrasi, Indonesia memiliki kebebasan untuk memilih mitra dagang yang paling menguntungkan diluar ASEAN.Namun, sejak tahun 1992 hingga sekarang, situasi yang terjadi sangatlah berbeda dengan adanya AFTA. Negara pendiri AFTA yang terdiri dari Indonesia, Thailand, Malaysia, Singapura, dan Filipina serta Brunei merupakan kelompok pertama yang terkena skema pengurangan tariff perdagangan atau dalam istilah terkenalnya adalah pemberlakuanCommon Effective Preferential Tariff (CEPT). Secara terminologi, CEPT adalah kerjasama antar anggota negara ASEAN dalam menurunkan tariff perdagangan serta menghapus hambatan non-tarif yang telah dimulai sejak 1 Januari 1993 (asean.org). Selanjutnya, kelompok kedua yang terdiri dari Kamboja, Laos, Myanmar, dan Vietnamakan mengikuti jejak kelompok pertama dalam penerapan CEPT.

Selanjutnya, saat strategi CEPT masih berjalan, ASEAN telah menyepakati komitmen untuk meneruskan kesinambungan proses integrasi di ASEAN melalui mekanisme Cetak Biru Masyarakat Ekonomi ASEAN atau ASEAN Economic Community (AEC) Blueprint 2008 dan Buku Piagam Masyarakat Ekonomi ASEAN(AEC chart-book, 2009). Tujuan utama dari kedua skema tersebut adalah terintegrasinya sektor-sektor penting di tahun 2015.Untuk mencapai tujuan tersebut, ASEAN mengutamakan tujuh sektor yang sesuai dengan keunggulan kompetitif ASEAN di masa mendatang. Ketujuh sektor tersebut adalah produk berbasis agro, otomotif, elektronik, perikanan, produk olahan darikaret, tekstil, pakaian, dan produk olahan dari kayu. Namun, makalah ini hanya membahas beberapa sektor saja seperti produk berbasis agro, perikanan, produk olahan dari karet, dan produk olahan dari kayu. Hal ini dikarenakan Indonesia memiliki keunggulan kompetitif di sektor-sektor tersebut dibandingkan pesaingnya.

Oleh karenanya, makalah ini bertujuan untuk menganalisis sektor-sektor pilihan tersebut. Bagian terpenting dari makalah iniadalah untuk mengetahui kelebihan dan kelemahan sektorsektor pilihan tersebut yang dibandingkan dengan mitra dagang ASEAN yakni: Malaysia, Filipina, Singapura, Thailand, dan Brunei; sejalan dengan AFTA 2015. Selanjutnya, makalah ini menggunakan model persamaan gravitasi yang telah dirubah. Model ini berfungsi untuk menjelaskan interpretasi hasil regresi dari model berdasarkan parameter tingkat signifikansi koefisien dari variabel dan parameter Koefisien Determinasi yang telah disesuaikan atau adjusted $R$-square nya. Jadi, kajian ini dapat menjelaskan dinamika perdagangan antara Indonesia dan mitra daganganya dari ASEAN dengan cara yang tepat.

Bagian selanjutnya dari paper ini adalah teori integrasi ekonomi, bagian kedua akan membahas metodologi dan data yang digunakan, serta hasil estimasi model dan analisisnya disajikan pada bagian 4. Kesimpulan dan implikasi studi ini disajikan pada bagian terakhir sekaligus sebagai penutup makalah ini. 


\section{TEORI}

\section{Integrasi Ekonomi}

Venables (2000) menjelaskan bahwa integrasi yang dimaksudkan adalah integrasi ekonomi regional yang terjadi saat beberapa negara membentuk sebuah pakta perdagangan bebas yang tujuannya membuka akses perdagangan seluas mungkin satu sama lain. Venables juga menekankan makna integrasi regional ke sebuah pemahaman mendalam tentang perdagangan internasional lebih dari sekedar penghapusan tarif impor dan kuota untuk menghilangkan segmentasi pasar dengan menyerukan totalitas integrasi kedalam ranah yang lebih tinggi. Integrasi ekonomi dimaknai sebagai penghapusan hambatan ekonomi antara dua ekonomin egara atau lebih (Pelksman, 2006). Dia menjelaskan bahwa integrasi ekonomi bertujuan untuk meningkatkan kompetisi yang sifatnya berpotensi untuk kemakmuran bersama. Kompetisi antar para pelaku pasar akan menyebabkan penurunan harga untuk barang dan jasa yang sejenis, dengan demikian bisa meningkatkan kualitas dan memperbanyak pilihan bagi konsumen pada wilayah yang terintegrasi. Ada beberapa bentuk integrasi (El-Agraa, 1997), akan tetapi inti dari integrasi sendiri adalah penghapusan diskriminasi hambatan perdagangan antara, paling tidak, dua negara yang berpartisipasi dan tawaran beberapa bentuk kerja sama dan koordinasi antar negara-negara yang berpartisipasi. Tabel 1 dibawah ini menjelaskan tahapantahapan oleh El-Agraa:

\begin{tabular}{|c|c|c|c|c|c|}
\hline \multicolumn{6}{|c|}{$\begin{array}{c}\text { Tabel } 1 . \\
\text { Karakteristik Integrasi Ekonomi Internasional }\end{array}$} \\
\hline Jenis & $\begin{array}{l}\text { Perdagangan } \\
\text { Bebas dengan } \\
\text { memberlakukan } \\
\text { Tarif Sendiri } \\
\text { untuk Non- } \\
\text { Anggota (Free } \\
\text { Trade Area) }\end{array}$ & $\begin{array}{l}\text { Perdagangan } \\
\text { Bebas dengan } \\
\text { Memberlakukan } \\
\text { Tarif Bersama } \\
\text { untuk Non- } \\
\text { Anggota } \\
\text { (Custom Union) }\end{array}$ & $\begin{array}{l}\text { Penyatuan } \\
\text { Pasar }\end{array}$ & $\begin{array}{l}\text { Penyatuan } \\
\text { secara } \\
\text { Ekonomi }\end{array}$ & $\begin{array}{c}\text { Penyatuan } \\
\text { Secara } \\
\text { Ekonomi dan } \\
\text { dikuatkan } \\
\text { dengan } \\
\text { Komitmen } \\
\text { Politik }\end{array}$ \\
\hline \multicolumn{6}{|l|}{ Kebijakan } \\
\hline $\begin{array}{l}\text { Penghapusan Tarif } \\
\text { dan Kuota }\end{array}$ & $\sqrt{ }$ & $\sqrt{ }$ & $\sqrt{ }$ & $\sqrt{ }$ & $\sqrt{ }$ \\
\hline $\begin{array}{l}\text { Pemberlakuan tariff } \\
\text { bersama untuk } \\
\text { non-anggota }\end{array}$ & & $\sqrt{ }$ & $\sqrt{ }$ & $\sqrt{ }$ & $\sqrt{ }$ \\
\hline $\begin{array}{l}\text { Mobilitas Faktor } \\
\text { Produksi }\end{array}$ & & & $\sqrt{ }$ & $\sqrt{ }$ & $\sqrt{ }$ \\
\hline $\begin{array}{l}\text { Harmonisasi } \\
\text { Kebijakan Ekonomi }\end{array}$ & & & & $\sqrt{ }$ & $\sqrt{ }$ \\
\hline $\begin{array}{l}\text { Penyatuan dalam } \\
\text { Kebijakan Ekonomi }\end{array}$ & & & & & $\sqrt{ }$ \\
\hline
\end{tabular}


Selanjutnya, negara anggota perdagangan bebas menghapus semua hambatan perdagangan satu sama lain, akan tetapi setiap negara memiliki hak untuk menentukan jenis kebijakan yang akan diterapkan untuk negara yang tidak berpartisipasi dalam perdagangan bebas. Perjanjian tersebut termasuk penghapusan hambatan tarif dan non-tarif perdagangan seperti Kuota dan Subsidi. Inti dari komitmen dari perdangan bebas adalah hanya komoditas tertentu saja dari negara anggota yang tarifnya dihapus. Contoh perjanjian perdagangan bebas antara lain European Free Trade Association (EFTA), yang mencakup Inggris, Austria, Denmark, Norwegia, Portugal, Swedia, Swiss dan Finlandia serta North American Free Trade Area (NAFTA) yang dibentuk oleh Amerika Serikat, Kanada dan Mexico 1993.

Seperti halnya perdagangan bebas, Custom Unionjuga menghapus seluruh hambatan perdagangan antar negara yang berpartisipasi. Namun yang membedakan adalah negaranegara anggota menyelaraskan kebijakan perdagangan mereka dan memiliki tarif tunggal impor untuk negara-negara yang tidak berpartisipasi. Custom unions yang paling terkenal adalah European Common Marketyang dibentuk pada tahun 1957 oleh Jerman Barat, Perancis, Italia, Belgia, Belanda, serta Luxemburg. Isi dari penyatuan pasar adalah bebasnya mobilitas faktor produksi seperti tenaga kerja, modal, perusahaan, dan teknologi antar negara yang berpartisipasi.

\begin{tabular}{|c|c|}
\hline \multicolumn{2}{|c|}{$\begin{array}{c}\text { Tabel } 2 . \\
\text { Tahapan Penting Integrasi Ekonomi Menurut Balassa }\end{array}$} \\
\hline Tahapan & Uraian Ringkas \\
\hline $\begin{array}{l}\text { Tahap } 1 \\
\text { Perdagangan Bebas dengan } \\
\text { memberlakukan Tarif Sendiri untuk } \\
\text { Non-Anggota (Free Trade Area) }\end{array}$ & $\begin{array}{l}\text { - Tarif dan Kuota dihapuskan untuk impor dari negara anggota. } \\
\text { - Negara anggota tetap memberlakukan tarif (dan kuota) nasional bagi } \\
\text { negara ketiga. }\end{array}$ \\
\hline $\begin{array}{l}\text { Tahap } 2 \\
\text { Perdagangan Bebas dengan } \\
\text { Memberlakukan Tarif Bersama } \\
\text { untuk Non-Anggota } \\
\text { (Custom Union) }\end{array}$ & $\begin{array}{l}\text { - Menekan diskriminasi negara anggota Custom Union dalam pasar } \\
\text { produk. } \\
\text { - Penyamaan tarif perdagangan dengan negara bukan anggota. }\end{array}$ \\
\hline $\begin{array}{l}\text { Tahap } 3 \\
\text { Penyatuan Pasar }\end{array}$ & - Custom Union juga menghapus hambatan pergerakan faktor produksi. \\
\hline $\begin{array}{l}\text { Tahap } 4 \\
\text { Penyatuan Secara Ekonomi }\end{array}$ & $\begin{array}{l}\text { - Penyatuan Pasar adalah penyelarasan kebijakan ekonomi nasional } \\
\text { untuk menghapus perbedaan dikarenakan adanya kesenjangan antar } \\
\text { kebijakan. }\end{array}$ \\
\hline $\begin{array}{l}\text { Tahap } 5 \\
\text { Penyatuan Secara Ekonomi dan } \\
\text { dikuatkan dengan Komitmen Politik }\end{array}$ & $\begin{array}{l}\text { - Penyatuan kebijakan moneter, fiskal, sosial, } \\
\text { - Membentuk otoritas sentralyang aturannya mengikat seluruh negara } \\
\text { anggota. }\end{array}$ \\
\hline Sumber : Diadaptasi dari Balassa, 196 & \\
\hline
\end{tabular}


Uni Eropa (EU) telah berstatus Penyatuan Pasar sejak tahun 1992. Sedangkan Penyatuan Ekonomi merupakan penyatuan pasar yang melibatkan terintegrasinya kebijakan moneter dan fiskalnya antar anggota dimana Kebijakan moneter diatur oleh bank sentral yang dibentuk sendiri seperti Bank Sentral Eropa. Dan Bank Sentral Eropa berhak mengeluarkan mata uang tunggal yang bernama Euro. Keberadaan suatu otoritas sentral seperti Bank Sentral Eropa dianggap sebagai bentuk integrasi ekonomi paling maju yang pernah ada. Sehingga tahapan selanjutnya adalah penyatuan ekonomi yang diperkuat dengan komitmen politik dengan menghadirkan Dewan Parlemen Bersama. Uni eropa telah melangkah ke tahapan tertinggi ini. Sebagai tambahan, Balassa (1961) mengajukan tahapan penting untuk mewujudkan integrasi ekonomi. Tahapan tersebut diurai pada tabel di bawah ini:

Tahapan penting tersebut disajikan secara berurutan untuk dianalisis.Akan tetapi, tidak ada sebuah keharusan untuk mengikuti tahapan Balassa. European Economic Community membentuk sebuahCustom Union bukan Free Trade Area. Hal ini berbeda dengan NAFTA yang dimulai dengan strategi Free Trade Area.Tahapan ini merupakan integrasi ekonomi yang menjelaskan sistematika konsep untuk membangun sebuah integrasi ekonomi yang sebenarnya.

\section{Teori Fundamental Integrasi Perdagangan}

Perdagangan barang dan jasa internasional terbangunoleh adanya perbedaan sumber daya dan kemampuan tenaga kerja antar negara dan dikarenakan pilihan konsumen berbeda antara satu negara dengan yang lainnya. David Ricardo, seorang ekonom Inggris abad ke 19, mengemukakan bahwa sebuah negara dapat memperoleh keuntungan dari perdagangan tersebut walaupun negara lain memiliki kemampuan penuh untuk memproduksi seluruh barang dan jasa. la menyampaikan bahwa pemusatan produksi barang di negara yang relatif efisien untuk melakukannya, serta mengimpor produk-produk tersebut oleh negara yang tidak cukup efisien untuk memproduksinya sendiri, dapat meningkatkan pendapatan nasional. Hal ini juga berlaku untuk negara yang tidak cukup efisien dalam memproduksi seluruh produk. Dengan kata lain, Keunggulan atas dasar efisiensi membuat sebuah negara memiliki keunggulan komparatif. Dodge (2003) mengemukakan bahwa pada akhirnya, tekanan kompetitif akibat dari kehadiran perdangan bebas menghasilkan efisiensi yang lebih besar, produktifitas yang lebih besar, dan kelayakan hidup yang lebih tinggi. Di sisi lain, penyesuaian biaya sangat diperlukan untuk menghapus hambatan bagi perdagangan bebas. Ini merupakan bagian dari proses untuk memperoleh keuntungan dalam jangka pendek maupun dalam jangka panjang. Pelkmans (2006) mengemukakan bahwa integrasi perdagangan adalah proses signifikansi dari meningkatnya aktivitas perpindahan barang, jasa dan faktor produksi antar sesama anggota secara dramatis. 


\section{Perbedaan antara Free Trade Area (FTA) dan Custom Unions}

Sehubungan dengan FTA dan CU, Husted dan Melvin (2010) menjelaskan bahwa perbedaan antara FTA dan CU terletak pada bagaimana negara anggota memperlakukan negara bukan anggota. Sehingga, definisi dari FTA adalah kesepakatan antar beberapa negara untuk menghapus hambatan internal perdagangan akan tetapi tidak ada hambatan bagi negara bukan anggota sehingga dalam skema FTA negara anggota menerapkan tarif nasional bagi negara non-anggota yang disebut dengan istilah Most Favoured Nation (MFN) Tariff. CU adalah kesepakatan antar beberapa negara untuk menghapus hambatan internal perdagangan dan adanya hambatan bersama terhadap negara bukan anggota. Tarif yang berkaitan dengan penghapusan hambatan internal dikenal dengan sebutan Preferential Trade Arrangements (PTA). Secara terminologi, PTA adalah beberapa negara telah bersepakat untuk menghapus hambatan diantara mereka.

Di sisi lain, PTA melibatkan dan mempengaruhi tiga pelaku ekonomi negara-negara yang terlibat di FTA dan CU (Husted dan Melvin, 2010): pertama, konsumen, akan berada pada posisi consumer surplus atau consumer loss tergantung dari sisi ekspor dan impor. Consumer surplus adalah selisih antara konsumen yang bersedia membayar pembelian jumlah barang tertentu dan jumlah yang harus mereka bayarkan untuk membeli barang tersebut, begitu pun sebaliknya bagi consumer loss. Kedua, produsen, juga akan berapa pada posisi producer surplus dan producer loss bergantung pada sisi ekspor dan impor. Producer surplus adalah selisih antara harga yang dibayarkan dalam pasar untuk barang dan harga minimum yang berlaku pada industri atau pasar untuk berproduksi, begitu pun sebaliknya untuk producer loss. Ketiga adalah pemerintah menikmati penerimaan tariff.

Husted dan Melvin (2010) mengemukakan dengan tajam bahwa PTA memiliki dua implikasi ekonomi utama: pertama, pengalihan perdagangan (trade diversion) adalah pergeseran pola perdagangan yakni dari bertransaksi denganprodusen dengan biaya rendah (keunggulan komparatif yang alami) berpindah bertransaksi dengananggota CU atau FTA yang memiliki biaya tinggi. Konsekuensi dari pengalihan perdagangan adalah consumer loss, producer surplus, danpenerimaan pmerintah dari tarif berkurang. Kedua, penciptaan perdagangan (trade creation) merupakan perluasan di dunia perdagangan yang lahir dari terbentuknya PTA. Akibatnya adalah bergantinya produksi domestik barang impor berbiaya tinggi dengan impor berbiaya rendah yang menyebabkan consumer surplus, producer loss, dan penerimaan tariff pun berkurang.

Strategi optimal terkait kedua implikasi ekonomi PTA tersebut adalah maksimisasi penciptaan perdagangan dan minimisasi pengalihan perdaganganakan menguntungkan FTA dan CU. Selain berpengaruh terhadap pelaku ekonomi dan memiliki implikasi ekonomi, PTA, dalam perdagangan bebas, memperoleh keuntungan dari sisi impor maupun ekspor (Husted dan Melvin, 2010): pertama, dari sisi negara importir, PTA akan memperoleh keuntungan bagi konsumen dan merugikan produsen domestik; hal ini dikarenakan konsumen mampu membeli produk tersebut dengan harga yang lebih murah sehingga membuat produsen mengurangi 
kuantitas produksinya hingga keluar dari pasar. Kedua, dari sisi negara eksportir, PTA akan menguntungkan produsen dan merugikan konsumen; hal ini dikarenakan produsen dalam negeri akan menambah output nya dikarenakan tingginya harga dari sesama anggota FTA atau CU. Hal ini membuat permintaan konsumen pun menurun.

\section{Model Persamaan Gravitasi}

Model Persamaan Gravitasi telah digunakan secara luas pada berbagai sektor-sektor seperti migrasi, Foreign Direct Investment, dan banyak lagi terkait perdagangan internasional serta menjadi alat yang dapat diandalkan untuk menganalisis fenomena perdagangan bebas. Persamaan dasar dari model gravitasi adalah:

$$
T_{i j}=A \times Y_{i}^{a} \times Y_{j}^{b} / D_{i j}^{c}
$$

$T_{i j}$ adalah nilai perdagangan antara negara I dan negara j, $Y_{i}$ adalah PDB negara I, $Y_{j}$ adalah PDB negara j, $D_{i j}$ dan adalah jarak diantara kedua negara. Model persamaan Gravitasi ini dikutip dari teori Krugman dan Obstfeld (2009). Mereka juga mengemukakan bahwa latar belakang penamaan Gravitasi pada model ini merupakan analogi dari teori gravitasi Newton: layaknya gaya tarik gravitasi diantara dua obyek bersifat proporsional terhadap massa dan makin berkurang dengan adanya jarak. Perdagangan antar dua negara, hal lain dianggap sama, bersifat proporsional terhadap PDB dan berukurang seiring dengan bertambahnya jarak.

Sebagai tambahan, ada tiga pernyataan kuat dari Krugman dan Obstfeld (2009) tentang model Gravitasi: Terdapat hubungan empiris yang kuat antara besaran perekonomian sebuah negara dengan impor dan ekspornya. Kedua, terkait dengan logika model Gravitasi: Mengapa model Gravitasi berfungsi? Umumnya, ekonomi yang besar cenderung banyak melakukan impor dikarenakan mereka memiliki banyak pemasukan. Mereka juga cenderung menyerap pengeluaran dari negara lain dikarenakan besarnya jumlah produksi mereka.

Sehingga, perdagangan antar dua negara menjadi lebih luas. Ketiga, terkait dengan hadirnya anomaly perdagangan yakni salah satu prinsip penggunaan model Gravitasi adalah untuk membantu kita mengidentifikasi terjadinya anomali dalam perdagangan. Para ekonom memang membutuhkan penjelasan lebih dalam saat perdagangan antar dua negara melebihi atau bahkan kurang dari prediksi model Gravitasi. Akan tetapi, beberapa studi telah menurunkan persamaan model Gravitasi menjadi formasi yang dirubah berdasarkan tinjauan perdagangan bebas yang bersifat bilateral atau regional. Tabel 3 menjelaskan beberapa model persamaan Gravitasi yang telah dirubah. 


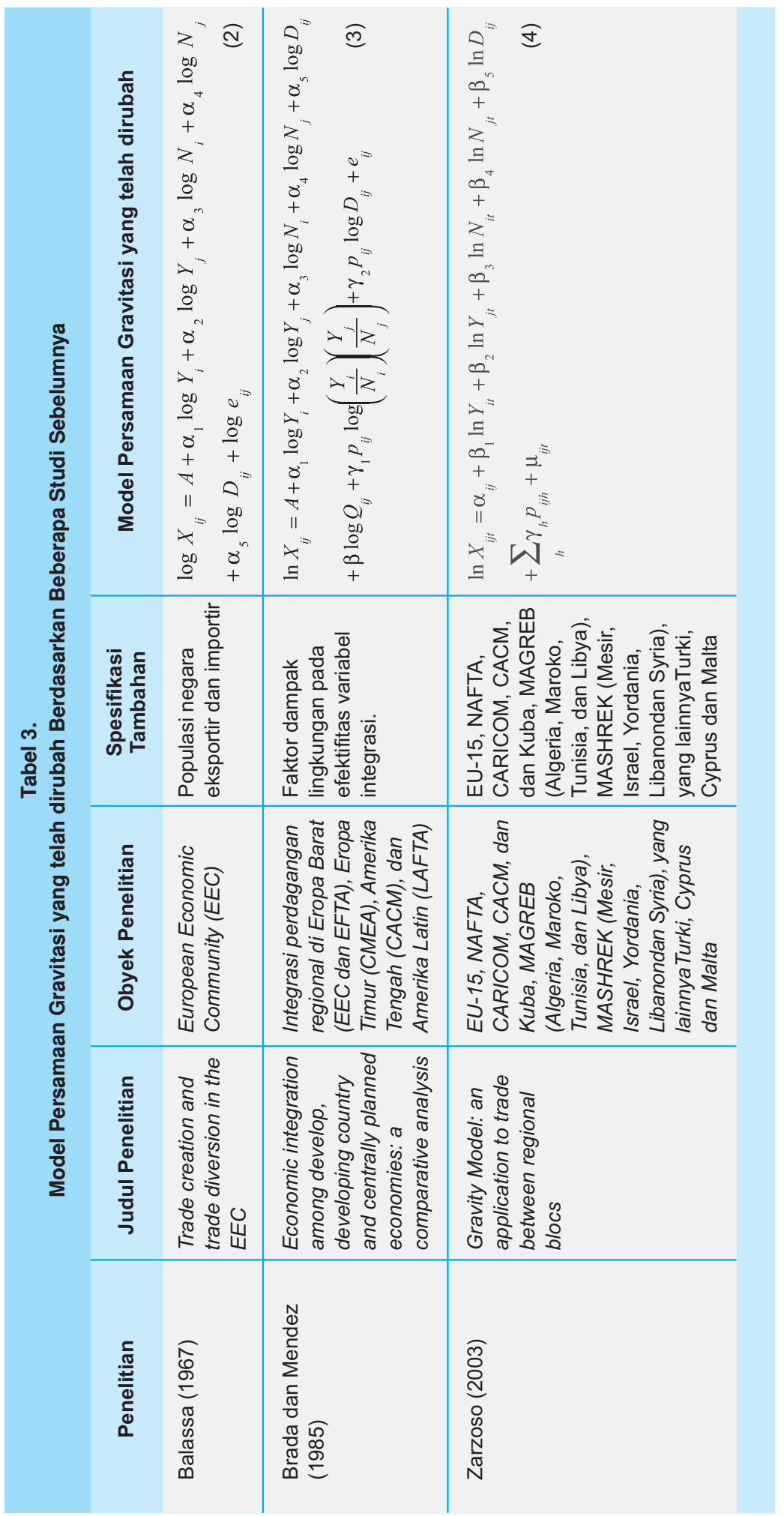


Dampak dari adanya model persamaan model Gravitasi yang telah dirubah pada poin sebelumnya mendorong analisis yang lebih dalam dikarenakan adanya dinamika perdagangan. Tabel di bawah ini menjelaskan tentang makna dari koefisien persamaan model Gravitasi yang telah dikembangkan:

\begin{tabular}{|c|c|}
\hline \multicolumn{2}{|c|}{$\begin{array}{l}\text { Tabel } 4 . \\
\text { Interpretasi Parameter Berdasarkan Studi Sebelumnya }\end{array}$} \\
\hline Studi Empiris & Interpretasi Parameter \\
\hline Calvo-Pardo, et.al (2009) & $\begin{array}{l}\text { - Jika koefisien tarif perdagangan yang telah dikurangi besarannya bernilai } \\
\text { negatif, maka biaya impor lebih besar dibandingkan yang lainnya, begitu } \\
\text { pun sebaliknya. }\end{array}$ \\
\hline Pacheco and Pierola (2008) & $\begin{array}{l}\text { - Prakiraan PDB riil atau PDB Per Kapita serta jarak untuk menunjukkan } \\
\text { masing-masing koefisien bernilai positif atau negatif. } \\
\text { - Hasil yang didapatkan dari variabel gravitasi mencerminkan makin besar } \\
\text { pasar yang menjadi tujuan serta makin dekat pasar tersebut (biaya } \\
\text { perdagangan yang lebih rendah), maka makin besar peningkatan volume } \\
\text { ekspornya. }\end{array}$ \\
\hline Zarzoso (2003) & $\begin{array}{l}\text { - Tingginya tingkat pendapatan negara eksportir mengindikasikan tingginya } \\
\text { tingkat produksi yang meningkatkan ketersediaan barang untuk diekspor. } \\
\text { Maka dari itu, koefisiennya harus bernilai positif. } \\
\text { - } \quad \text { Tingginya tingkat pendapatan negara importir menjadikannya perlu } \\
\text { meningkatkan impor sehingga koefisiennya bernilai positif } \\
\text { - Estimasi koefisien populasi eksportir dapat bernilai negatif atau positif } \\
\text { tergantung dari apakah negara tersebut mengekspor lebih sedikit (absorption } \\
\text { effect) atau apakah negara besar mengekspor lebih banyak ketimbang } \\
\text { negara kecil (economies of scale) } \\
\text { - Koefisien populasi importir juga memiliki tanda yang ambigu untuk alasan } \\
\text { yang sama }\end{array}$ \\
\hline Tamirisa (1999) & $\begin{array}{l}\text { - Jarak memiliki dampak negatif yang signifikan pada ekspor yang bersifat } \\
\text { bilateral dikarenakan biaya perdagangan (seperti transportasi dan } \\
\text { komunikasi) dapat meningkat tergantung seberapa jauh jarak yang ditempuh. } \\
\text { - Hambatan tarif negara importir juga cenderung memberikan pengaruh } \\
\text { negatif dan tidak signifikan terhadap negara-negara tersebut. } \\
\text { - Di sisi lain PDB dan populasi berpengaruh positif terhadap ekspor yang } \\
\text { bersifat bilateral. }\end{array}$ \\
\hline Brada dan Mendez (1985) & $\begin{array}{l}\text { - Variabel pendapatan dan populasi adalah pilihan dan sokongan dari } \\
\text { negara-negara yang terlibat dalam perdagangan. Seluruh koefisien harus } \\
\text { bernilai positif karena produktifitas dan pendapatan yang meningkat } \\
\text { mendorong untuk dilakukannya perdagangan. } \\
\text { - Negara besar memiliki produk yang lebih beragam sehingga memenuhi } \\
\text { proporsi permintaan domestik sedangkan negara kecil cenderung lebih } \\
\text { terspesialisasi sehingga lebih bergantung pada perdagangan. Hal ini } \\
\text { menyebabkan koefisiennya harus bernilai negatif. } \\
\text { - Populasi negara importir berpengaruh positif terhadap volume perdagangan } \\
\text { karena besarnya populasi menyebabkan besarnya jumlah tenaga yang } \\
\text { dapat dipekerjakan serta produk lebih bervariasi. Hal ini menyebabkan } \\
\text { barang impor bersaing dengan produk domestic dan akan berpengaruh } \\
\text { pada tahapan proses produksi. Lebih lanjut, pasar yang besar seharusnya } \\
\text { menguntungkan eksportir sehingga koefisiennya harus bernilai positif. }\end{array}$ \\
\hline
\end{tabular}




\section{METODOLOGI}

Makalah ini menggunakan model persamaan model Gravitasi yang telah dirubah sebagai berikut:

$\log \sum$ TBRubber $_{i j}=\alpha_{1}+\alpha_{2} \log Y_{i}+\alpha_{3} \log Y_{j}+\alpha_{4} \log D_{i j}+\alpha_{5} \log t_{i}$

$+\alpha_{6} \log t_{j}+\alpha_{7} \log e x_{i}+\alpha_{8} \log e x_{j}+\log e_{i j}$

$\log \sum$ TBWood $_{i j}=\alpha_{1}+\alpha_{2} \log Y_{i}+\alpha_{3} \log Y_{j}+\alpha_{4} \log D_{i j}+\alpha_{5} \log t_{i}$

$+\alpha_{6} \log t_{j}+\alpha_{7} \log e x_{i}+\alpha_{8} \log e x_{j}+\log e_{i j}$

$\log \sum$ TBAgro $_{i j}=\alpha_{1}+\alpha_{2} \log Y_{i}+\alpha_{3} \log Y_{j}+\alpha_{4} \log D_{i j}+\alpha_{5} \log t_{i}$

$+\alpha_{6} \log t_{j}+\alpha_{7} \log e x_{i}+\alpha_{8} \log e x_{j}+\log e_{i j}$

$\log \sum$ TBFisheris ij $_{1}=\alpha_{1}+\alpha_{2} \log Y_{i}+\alpha_{3} \log Y_{j}+\alpha_{4} \log D_{i j}+\alpha_{5} \log t_{i}$

$+\alpha_{6} \log t_{j}+\alpha_{7} \log e x_{i}+\alpha_{8} \log e x_{j}+\log e_{i j}$

Dimana:

- $\quad \Sigma_{T B_{i j}}$ adalah total nilai neraca perdagangan (net exports) produk yang terbuat dari karet, produk yang terbuat dari kayu, produk berbasis agro, dan perikanan dari Indonesia ( $I$ ) terhadap anggota negara ASEAN yang dipilih (j) dalam US Dollar;

- $\quad \alpha_{1}$ adalah efek yang konstan atau tidak diamati;

- $\quad Y_{i t}, Y_{j t}$ adalah PDB Per Kapita Indonesia dan PDB Per Kapita negara anggota ASEAN yang dipilih dalam US Dollar.

- $\quad D_{i j}$ adalah jarak antara ibu kota Indonesia ( $(I)$ dan ibu kota negara anggota ASEAN (j) yang dipilih dalam kilometer;

- $t_{i}$ adalah tingkat CEPT rata-rata Indonesia (I) dalam persentase;

- $\quad t_{j}$ adalah tingkat CEPT rata-rata negara anggota ASEAN (j) dalam persentase;

- ex adalah nilai tukar mata uang Indonesia (I) per US Dollar;

- $\quad e x_{j}$ adalah nilai tukar mata uang negara anggota ASEAN yang dipilih (j) per US Dollar;

- $e_{i j}$ adalah log normal error term 
Data yang digunakan masing-masing berasal dari International Trade Center ${ }^{2}$ yang berisi data neraca perdagangan. Data PDB Per Kapita ditambah CEPT, jarak, dan nilai tukar riil diperoleh dari ASEAN dan sumber lainnya ${ }^{3}$, dan International Financial Statistic 2009. Periode waktu yang digunakan dari 2002 hingga 2008. Makalah ini mengestimasi dan memberikan analisis tentang pentingnya signifikansi suatu koefisien. Pertama, tingginya pendapatan negara eksportir mengindikasikan tingginya tingkat produksi yang mendorong tingginya ekspor. Nilai dari $\alpha_{2}$ yang positif dapat diartikan sebagai absorption effectatau berperan signifikan dalam zona perdagangan bebas. Kedua, nilai dari $\alpha_{3}$ juga harus positif (+) karena tingginya pendapatan negara importir mendorong impor yang lebih tinggi serta berhubungan dengan empat pilihan seperti: the absorption effect atau the scale of economies atau keunggulan komparatif alami, dan peran yang dimainkan. Ketiga, parameter jarak $\alpha_{4}$ diharapkan bernilai positif (+) karena proksi dari seluruh kemungkinan biaya perdagangan. Jarak memiliki pengaruh negatif yang signifikan pada ekspor yang bersifat bilateral karena biaya perdagangan (seperti tansportasi dan komunikasi) cenderung meningkat seiring jauhnya jarak tempuh atau sebaliknya.

Keempat, $\alpha_{5}$ seharusnya bernilai positif $(+)$ saat Indonesia menggunakan biaya impor yang lebih rendah (ACEPT rate) dibandingkan negara sesama anggota maka dalam hal ini, Indonesia merupakan negara importir dengan biaya rendah sehingga dapat dihubungkan dengan strategi penciptaan perdagangan. Kebijakan penciptaan akan memperoleh lebih banyak keuntungan dari perdagangan bebas. Kelima, koefisien $\alpha_{6}$ bernilai negatif sehingga biaya ekspor Indonesia (ACEPT rate) menjadi lebih rendah dibandingkan negara anggota lain yang dipilih. Jadi dapat disimpulkan bahwa Indonesia menerapkan strategi penciptaan perdagangan. Keenam, nilai dari $\alpha_{7}$ memiliki tanda negatif (-) tapi parameter $\alpha_{8}$ diperkirakan bernilai positif (+). Keduanya mengindikasikan bahwa Rupiah Indonesia (IDR) memiliki nilai yang lebih rendah dibandingkan nilai mata uang negara anggota lainnya. Akibatnya, neraca perdagangan Indonesia meningkat secara konstruktif mengingat harga produk Indonesia lebih murah dibandingkan harga produk pesaing.

Maka dari itu, paper makalah ini akan menggunakan metode Pooled Least Square (PLS) dimana akan sangat tepat diterapkan untuk datayang secara historis sedikit tetapi memiliki banyak rentang atau persilangan data (Gujarati and Porter, 2009). Selanjutnya Gujarati dan Porter (2009) menjelaskan manfaat dari data panel: pertama, dengan menggabungkan pengamatan data historis dan data rentang atau persilangan dimana data panel memberikan data yang lebih jelas, lebih beragam, less collinearity antar variabel, dan more degree of freedom serta lebih efisien. Kedua, dengan mempelajari data rentang atau persilangan serta melakukan observasi yang berulang, dapat dimanfaatkan untuk mempelajari dinamika perubahan. Ketiga, data panel mampu untuk mendeteksi dan mengukur pengaruh dengan lebih baik yang tidak dapat diamati dengan data hanya bersifat historikal atau hanya data rentang/persilangan.

2 Diunggah dari www.trademap.org.

3 Tersedia pada www.asean.org, www.indo.com/distance dan www.geobytes.com/citydistancetool.htm. 
Keempat, data panel memungkinkan kita untuk mempelajari model perilaku yang lebih kompleks.

Regresi PLS mengasumsikan bahwa variabel penjelasnya (variabel independen) tidak stochastic. Jika variabel tersebut stochastic maka tidak akan berkorelasi dengan error term nya. Biasanya juga diasumsikan memiliki sifat yang sangat eksogen. Sebua variabel dikatakan sangat eksogen saat tidak bergantung pada nilai error termsaat ini, masa lalu, dan masa mendatang (Gujarati dan Porter, 2009). Hal ini juga dapat diasumsikan bahwa error termnya adalah $e_{i j} \sim$ idd $\left(0, \sigma^{2}\right)$, sehingga terdistribusi secara independen dan identik dengan zero mean dan varians yang konstan serta dapat diasumsikan bahwa error term nya terdistribusi normal.

Hasil dari PLS menyajikan dua estimasi sebagai dasar untuk menganalisis perdagangan multilateral Indonesia dengan beberapa pihak: pertama, prob. (t-stat) atau t test atau uji hipotesis tentang koefisien individu secara parsial, khususnya untuk variabel penjelas terhadap variabel dependen. Untuk uji hipotesis, jika $\rho$-valueatau prob. (t-stat) lebih kecil dari tingkat signifikansinya $\alpha$ sebesar 1\%,5\%, atau 10\%, maka hipotesis null nya ditolak. Hal ini mengimplikasikan bahwa independen variabel tersebut dipengaruhi oleh variabel dependen secara parsial (Gujarati dan Porter, 2009). Estimasi ini berfungsi untuk menghasilkan interpretasi yang jelas untuk mengungkap pola perdagangan.

Kedua, Koefisien Determinasi yang telah disesuaikan atau adjusted $R^{2}$ merupakan pengukuran hubungan regresi, pengukuran tentang sejauh apa regresi cocok dengan data yang ada (Azcel, 1995). Azcel juga mengemukakan bahwa semakin besar nilai koefisien determinasi $R^{2}$ semakin bagus maupun sebaliknya. Azcel mengelaborasi nilai $R^{2}$ sebesar 0.9 atau lebih sangatlah baik, nilai 0.6 atau lebih adalah memuaskan, dan nilai 0.5 atau kurang adalah buruk. Dengan merujuk kepada Azcel, makalah ini menggunakan kriteria yang berbeda karena penggunaan adjusted $R^{2}$. Kisaran interval adjusted $R^{2}$ dari $0 \%$ sampai $25 \%$; $26 \%$ sampai 50\%; dan 51\% sampai 100\% masing-masing mengimplikasikan sektor yang buruk di Indonesia, sektor yang lemah di Indonesia, dan sektor yang kuat di Indonesia secara berurutan.

\section{HASIL DAN ANALISIS}

Tabel di bawah ini menjelaskan regresi model persamaan gravitasi yang telah dikembangkan:

Informasi yang diberikan pada tabel 5 menjelaskan estimasi yang signifikan dari koefisien PDB per Kapita Indonesia terhadap Filipina, Singapura, dan Thailand. Akan tetapi, koefisien PDB per Kapita Indonesia tidak cukup untuk menjelaskan dinamika perdagangan antara Indonesia dan negara-negara yang telah disebutkan sebelumnya. Dengan demikian, PDB per kapita Filipina, Singapura, dan Thailand juga dipertimbangkan. PDB per kapita Filipina, Singapura, dan Thailand juga memiliki nilai yang besar namun memiliki notasi yang berlawan dengan Indonesia. 


\begin{tabular}{|c|c|c|c|c|c|}
\hline \multicolumn{6}{|c|}{$\begin{array}{l}\text { Tabel } 5 . \\
\text { Persamaan Gravitasi yang telah Dirubah dan telah Diestimasi untuk Sektor Produk Olahan dari Karet }\end{array}$} \\
\hline Indonesia to: & Brunei & Malaysia & Filipina & Singapura & Thailand \\
\hline Konstanta & $\begin{array}{c}69.54481^{*} \\
(0.0000)\end{array}$ & $\begin{array}{c}62.08589^{*} \\
(0.0000)\end{array}$ & $\begin{array}{c}89.70640^{*} \\
(0.0000)\end{array}$ & $\begin{array}{c}80.91527^{*} \\
(0.0000)\end{array}$ & $\begin{array}{l}26.31651^{* * *} \\
(0.0351)\end{array}$ \\
\hline$Y_{i}$ & $\begin{array}{l}-3.311988 \\
(0.1351)\end{array}$ & $\begin{array}{c}2.923614 \\
(0.3621)\end{array}$ & $\begin{array}{c}-2.025016^{*} \\
(0.0016)\end{array}$ & $\begin{array}{c}-2.231605^{*} \\
(0.0006)\end{array}$ & $\begin{array}{c}-2.091311^{*} \\
(0.0000)\end{array}$ \\
\hline$Y_{j}$ & $\begin{array}{l}-0.930077 \\
(0.6104)\end{array}$ & $\begin{array}{l}-6.063400^{* * *} \\
(0.0819)\end{array}$ & $\begin{array}{c}-3.397438^{*} \\
(0.0002)\end{array}$ & $\begin{array}{c}-3.193488^{*} \\
(0.0003)\end{array}$ & $\begin{array}{c}-1.281840^{* * *} \\
(0.0513)\end{array}$ \\
\hline$D_{i j}$ & $\begin{array}{c}-14.62007^{*} \\
(0.0002)\end{array}$ & $\begin{array}{c}-13.63169^{*} \\
(0.0001)\end{array}$ & $\begin{array}{c}-19.46577^{*} \\
(0.0000)\end{array}$ & $\begin{array}{c}-16.82774^{*} \\
(0.0001)\end{array}$ & $\begin{array}{c}-2.370968 \\
(0.4434)\end{array}$ \\
\hline$t_{i}$ & $\begin{array}{c}-3.79719^{* *} \\
(0.0203)\end{array}$ & $\begin{array}{c}-0.569571 \\
(0.7713)\end{array}$ & $\begin{array}{c}-0.901370 \\
(0.5606)\end{array}$ & $\begin{array}{c}-1.289047 \\
(0.3631)\end{array}$ & $\begin{array}{c}1.704444^{* * *} \\
(0.0701)\end{array}$ \\
\hline$t_{j}$ & $\begin{array}{c}-0.038478 \\
(0.9635)\end{array}$ & $\begin{array}{c}-0.542890 \\
(0.7818)\end{array}$ & $\begin{array}{c}-1.118072 \\
(0.4741)\end{array}$ & $\begin{array}{c}-0.903995 \\
(0.5320)\end{array}$ & $\begin{array}{c}-3.094332 \\
(0.0007)\end{array}$ \\
\hline$e x_{i}$ & $\begin{array}{c}0.307146 \\
(0.7252)\end{array}$ & $\begin{array}{c}-0.677290 \\
(0.4547)\end{array}$ & $\begin{array}{c}1.081600^{*} \\
(0.0006)\end{array}$ & $\begin{array}{c}0.887683^{* *} \\
(0.0123)\end{array}$ & $\begin{array}{c}-0.089683 \\
(0.7138)\end{array}$ \\
\hline$e x_{j}$ & $\begin{array}{c}-0.015210 \\
(0.9888)\end{array}$ & $\begin{array}{l}1.261404 \\
(0.2777)\end{array}$ & $\begin{array}{c}-0.360184 \\
(0.2795)\end{array}$ & $\begin{array}{c}-0.170639 \\
(0.6583)\end{array}$ & $\begin{array}{c}0.836867^{*} \\
(0.0026)\end{array}$ \\
\hline N. $A d j . R^{2}$ & $\begin{array}{c}63 \\
0.318435\end{array}$ & $\begin{array}{c}63 \\
0.248718\end{array}$ & $\begin{array}{c}63 \\
0.433426\end{array}$ & $\begin{array}{c}63 \\
0.446564\end{array}$ & $\begin{array}{c}63 \\
0.726532\end{array}$ \\
\hline
\end{tabular}

Akibatnya Indonesia adalah pengimpor produk akhir yang terbuat dari karet khususnya dari Singapura dan Thailand seperti ban untuk otomotif. Sebagai gantinya adalah produk olahan karet Indonesia diekspor dalam bentuk mentah dan barang setengah jadi ke Singapura, Thailand dan Filipina. Signifikansi parameter jarak diatributkan pada negara Brunei, Malaysia, Singapura, dan Thailand. Akan tetapi, negara-negara tersebut memiliki estimasi yang bernilai negatif dan berhubungan dengan meningkatnya biaya perdagangan seperti transportasi, komunikasi, dan administrasi. Contohnya adalah seperti perdagangan Indonesia dalam bentuk produk olahan karet ke Brunei. Sebelum adanya kesepakatan perdagangan, transaksi produsen Indonesia adalah $14.6 \%$ dari total seluruh biaya transaksi perdagangan. Makalah ini menunjukkan bahwa biaya perdagangan ke Filipina adalah yang termahal sebesar 19.5\%.

Estimasi notasi $t_{i}$ dan $t_{j}$ mengkaji penggunaan tarif ACEPT. Signifikansi ACEPT cukup nampak diantara Indonesia dengan Thailand dan hanya berfokus pada ACEPT Indonesia yang lebih rendah dari Thailand sebesar $1.7 \%$. Informasi sebelumnya menyimpulkan bahwa Indonesia sebagai negara importir dapat mengaplikasikan strategi penciptaan perdagangan. Strategi ini menguntungkan konsumen Indonesia karena harga yang relatif lebih murah dibandingkan dengan produk olahan karet dalam negeri. Hal ini membuat produsen Indonesia mengalami kerugian sebesar $1.7 \%$ karena masuknya produk jadi atau akhir tersebut. Produsen Indonesia akan mendapatkan manfaat hanya bila Indonesia mengimpor barang mentah dan barang 
setengah jadi. Dengan cara itu produsen Indonesia sejarusnya dapat berhemat hingga 1.7\% . Faktanya, pemerintah Indonesia sebagai pihak ketiga malah menderita kerugian penurunan pendapatan tarif sebesar $1.7 \%$.

Estimasi notasi Bath Thailand (THB) mengimplikasikan besarnya perbedaan yang terjadi terhadap Rupiah Indonesia (IDR). Akibatnya, jika THB menguat atas IDR maka net ekspor Indonesia akan meningkat kurang lebih $0.83 \%$ atau sebaliknya. Selanjutnya, informasi penting pada tabel 5 adalah estimasi adjusted $R^{2}$ yang membandingkan produk karet Indonesia dengan negara anggota ASEAN lainnya. Makalah ini menemukan bahwa produk olahan karet merupakan sektor andalan Indonesia untuk diperdagangkan dengan Thailand (72.65\%). Meskipun demikian, sisanya tidak signifikan untuk diperdagangkan dikarenakan estimasinya yang lemah.

Tabel 6 di bawah ini menggambarkan dua pengaruh yang berhubungan dengan estimasi PDB per kapita. Pertama, estimasi yang signifikan dan tanda positif dari PDB per kapita Indonesia mengindikasikan bahwa Indonesia mengekspor produk kayu ke Brunei dalam jumlah yang sangat besar. Kedua, dengan tingkat signifikansi yang sama tapi PDB per kapita Indonesia bertanda negatif, maka tak dapat diragukan lagi bahwa Indonesia membuka pintu perdagangan (impor) dengan Malaysia, Filipina, Singapura, dan Thailand.

Temuan ini cukup masuk akal bahwa Indonesia tidak terlalu ketat untuk mendorong ekspor ke negara-negara tersebut. Perlu dicatat bahwa impor dari negara-negara tersebut

\begin{tabular}{|c|c|c|c|c|c|}
\hline \multicolumn{6}{|c|}{$\begin{array}{l}\text { Tabel } 6 . \\
\text { Persamaan Gravitasi yang telah Dirubah dan telah Diestimasi untuk Sektor Produk } \\
\text { yang Terbuat dari Olahan Kayu }\end{array}$} \\
\hline Indonesia to: & Brunei & Malaysia & Filipina & Singapura & Thailand \\
\hline Konstanta & $\begin{array}{c}-27.90990 \\
(0.1132)\end{array}$ & $\begin{array}{c}59.66644^{*} \\
(0.0000)\end{array}$ & $\begin{array}{c}58.21403^{*} \\
(0.0001)\end{array}$ & $\begin{array}{c}41.79043^{* *} \\
(0.0136)\end{array}$ & $\begin{array}{c}48.18736^{* *} \\
(0.0174)\end{array}$ \\
\hline$Y_{i}$ & $\begin{array}{c}9.186632^{*} \\
(0.0008)\end{array}$ & $\begin{array}{c}-7.485078^{*} \\
(0.0000)\end{array}$ & $\begin{array}{c}-2.841708^{*} \\
(0.0000)\end{array}$ & $\begin{array}{c}-2.559711^{*} \\
(0.0004)\end{array}$ & $\begin{array}{c}-2.660826^{*} \\
(0.0002)\end{array}$ \\
\hline$Y_{j}$ & $\begin{array}{c}-4.0585^{\star * *} \\
(0.0622)\end{array}$ & $\begin{array}{c}3.076818^{*} \\
(0.0005)\end{array}$ & $\begin{array}{c}1.225369 \\
(0.1435)\end{array}$ & $\begin{array}{c}1.517875 \\
(0.1032)\end{array}$ & $\begin{array}{c}1.739184^{* * *} \\
(0.0989)\end{array}$ \\
\hline$D_{i j}$ & $\begin{array}{c}4.223679 \\
(0.3270)\end{array}$ & $\begin{array}{c}-10.88413^{*} \\
(0.0004)\end{array}$ & $\begin{array}{c}-14.43766^{*} \\
(0.0000)\end{array}$ & $\begin{array}{c}-10.18010^{* *} \\
(0.0195)\end{array}$ & $\begin{array}{c}-12.22422^{* *} \\
(0.0170)\end{array}$ \\
\hline$t_{i}$ & $\begin{array}{c}4.121848^{* *} \\
(0.0310)\end{array}$ & $\begin{array}{c}2.895193^{\star *} \\
(0.0649)\end{array}$ & $\begin{array}{c}2.971138^{* * *} \\
(0.0569)\end{array}$ & $\begin{array}{c}1.410275 \\
(0.3687)\end{array}$ & $\begin{array}{c}-0.389457 \\
(0.7940)\end{array}$ \\
\hline$t_{j}$ & $\begin{array}{c}0.039465 \\
(0.9681) \\
\end{array}$ & $\begin{array}{c}-2.837597^{\star * *} \\
(0.0729) \\
\end{array}$ & $\begin{array}{c}-2.495213 \\
(0.1105)\end{array}$ & $\begin{array}{c}-0.992821 \\
(0.5352) \\
\end{array}$ & $\begin{array}{l}0.916415 \\
(0.5093)\end{array}$ \\
\hline$e x_{i}$ & $\begin{array}{c}-2.967334^{*} \\
(0.0054)\end{array}$ & $\begin{array}{c}3.310880^{*} \\
(0.0000)\end{array}$ & $\begin{array}{c}1.622403^{*} \\
(0.0000)\end{array}$ & $\begin{array}{c}1.359832^{*} \\
(0.0008)\end{array}$ & $\begin{array}{c}1.582950^{*} \\
(0.0002)\end{array}$ \\
\hline$e x_{j}$ & $\begin{array}{c}3.284086^{* *} \\
(0.0122)\end{array}$ & $\begin{array}{c}-1.574310^{*} \\
(0.0000)\end{array}$ & $\begin{array}{c}-1.124434^{*} \\
(0.0012)\end{array}$ & $\begin{array}{c}-1.003077^{* *} \\
(0.0222)\end{array}$ & $\begin{array}{c}-1.267789^{*} \\
(0.0044)\end{array}$ \\
\hline N. Adj. $R^{2}$ & $\begin{array}{c}63 \\
0.442858\end{array}$ & $\begin{array}{c}63 \\
0.677137\end{array}$ & $\begin{array}{c}63 \\
0.669456\end{array}$ & $\begin{array}{c}63 \\
0.596437\end{array}$ & $\begin{array}{c}63 \\
0.577371\end{array}$ \\
\hline
\end{tabular}


hanya akan mendatangkan keuntungan untuk produk yang terbuat dari kayu dalam bentuk mentah atau barang setengah jadi untuk memberikan nilai tambah bagi produk yang terbuat dari olahan kayu. Pada akhirnya, barang bernilai tambah dapat disebar ke negara non anggota AFTA seperti Eropa, Amerika Serikat, Jepang, India, dan China. Strategi ini sangat berguna untuk meningkatkan surplus perdagangan. Meninjau kembali biaya perdagangan dengan parameter jarak, ternyata biaya perdagangan tertinggi dihabiskan oleh Filipina sebesar 14.3\% dari total transaksi yang dilakukan.

Pada kasus biaya impor, Indonesia dan Malaysia memiliki signifikansi estimasi yang sama. Tabel 6 menunjukkan bahwa Malaysia sebenarnya memiliki biaya impor yang lebih tinggi (ACEPT) dibandingkan Indonesia. Oleh karenanya, Indonesia dapat mengaplikasikan strategi pengalihan perdagangan atau penciptaan perdagangan. Saat menggunakan strategi pengalihan perdagangan, Indonesia bertindak sebagai eksportir. Akibatnya, produsen Indonesia mengalami kerugian sebesar 2.84\% karena menanggung tarif yang lebih tinggi. Untuk menghadapi hal ini, produsen Malaysia dapat meningkatkan harganya sesuai dengan produk kayu dari Indonesia. Keuntungan surplus ini diraih Malaysia sebesar 2.84\%. Meskipun demikian, konsumen Malaysia menderita kerugian hingga $2.8 \%$, tidak seperti pemerintah yang menikmati penerimaan tarif kurang lebih $2.8 \%$.

Bagaimana jika Indonesia berperan sebagai importir?Secara otomatis berlaku penciptaan perdagangan. Dampak penciptaan perdagangan lebih menguntungkan konsumen dibandingkan produsen di Indonesia. Konsumen Indonesia cukup puas mengkonsumsi produk kayu dari

\section{Tabel 7.}

Persamaan Gravitasi yang telah Dirubah dan telah Diestimasi untuk Sektor Produk Berbasis Agro

\begin{tabular}{|c|c|c|c|c|c|}
\hline Indonesia to: & Brunei & Malaysia & Filipina & Singapura & Thailand \\
\hline Konstanta & $\begin{array}{c}52.05350^{*} \\
(0.0011)\end{array}$ & $\begin{array}{c}67.35654^{*} \\
(0.0000)\end{array}$ & $\begin{array}{c}120.2942^{*} \\
(0.0000)\end{array}$ & $\begin{array}{c}108.5072^{*} \\
(0.0000)\end{array}$ & $\begin{array}{c}67.39194^{*} \\
(0.0000)\end{array}$ \\
\hline$Y_{i}$ & $\begin{array}{c}4.83860^{* * *} \\
(0.0334)\end{array}$ & $\begin{array}{c}-10.05339^{*} \\
(0.0038)\end{array}$ & $\begin{array}{c}-3.283774^{*} \\
(0.0000)\end{array}$ & $\begin{array}{c}-3.103830^{*} \\
(0.0000)\end{array}$ & $\begin{array}{c}-2.923801^{*} \\
(0.0000)\end{array}$ \\
\hline$Y_{j}$ & $\begin{array}{c}-8.376061^{*} \\
(0.0000)\end{array}$ & $\begin{array}{c}6.477341^{* * *} \\
(0.0740)\end{array}$ & $\begin{array}{c}-4.634652^{*} \\
(0.0000)\end{array}$ & $\begin{array}{c}-4.427253^{*} \\
(0.0000)\end{array}$ & $\begin{array}{c}-2.963539^{*} \\
(0.0002)\end{array}$ \\
\hline$D_{i j}$ & $\begin{array}{c}-9.36583^{\star *} \\
(0.0144)\end{array}$ & $\begin{array}{c}-14.72237^{*} \\
(0.0001)\end{array}$ & $\begin{array}{c}-25.68694^{*} \\
(0.0000)\end{array}$ & $\begin{array}{c}-22.61019^{*} \\
(0.0000)\end{array}$ & $\begin{array}{c}-11.82369^{*} \\
(0.0016)\end{array}$ \\
\hline$t_{i}$ & $\begin{array}{c}-3.76136^{\star *} \\
(0.0233)\end{array}$ & $\begin{array}{c}0.316496 \\
(0.8765)\end{array}$ & $\begin{array}{c}-0.251970 \\
(0.8567)\end{array}$ & $\begin{array}{c}-1.642878 \\
(0.2389)\end{array}$ & $\begin{array}{c}0.621297 \\
(0.5617)\end{array}$ \\
\hline$t_{j}$ & $\begin{array}{c}-0.305202 \\
(0.7206)\end{array}$ & $\begin{array}{c}-1.806658 \\
(0.3771)\end{array}$ & $\begin{array}{c}-1.943383 \\
(0.1709)\end{array}$ & $\begin{array}{c}-0.627888 \\
(0.6579)\end{array}$ & $\begin{array}{c}-2.221986^{* *} \\
(0.0291)\end{array}$ \\
\hline$e x_{i}$ & $\begin{array}{c}-3.252881^{*} \\
(0.0006)\end{array}$ & $\begin{array}{c}2.799426^{*} \\
(0.0043)\end{array}$ & $\begin{array}{c}1.504422^{*} \\
(0.0000)\end{array}$ & $\begin{array}{c}1.318602^{*} \\
(0.0003)\end{array}$ & $\begin{array}{c}0.603673^{* *} \\
(0.0367)\end{array}$ \\
\hline$e x_{j}$ & $\begin{array}{c}5.228125^{*} \\
(0.0000)\end{array}$ & $\begin{array}{c}-2.308180^{* * *} \\
(0.0592)\end{array}$ & $\begin{array}{c}0.405594 \\
(0.1786)\end{array}$ & $\begin{array}{c}0.483447 \\
(0.2050)\end{array}$ & $\begin{array}{c}1.212119^{*} \\
(0.0002)\end{array}$ \\
\hline N. Adj. $R^{2}$ & $\begin{array}{c}63 \\
0.607047\end{array}$ & $\begin{array}{c}63 \\
0.544942\end{array}$ & $\begin{array}{c}63 \\
0.741487\end{array}$ & $\begin{array}{c}63 \\
0.701265\end{array}$ & $\begin{array}{c}63 \\
0.795372\end{array}$ \\
\hline
\end{tabular}


Malaysia. Produsen Indonesia selanjutnya menerima potongan sebesar 2.9\% dengan mengimpor produk dalam bentuk mentah atau setengah jadi. Jika nilai tukar IDR menguat terhadap Peso Filipina (PHP), maka akan menurunkan net ekspor produk kayu Indonesia sebesar $0.5 \%$. Estimasi adjusted $R^{2}$ mengidentifikasi Malaysia (67.7\%), Filipina (66.95\%), Singapura (sekitar 60\%), dan Thailand (57.7\%) sebagai mitra dagang yang penting bagi Indonesia dalam skema AFTA. Hal ini mengimplikasikan tingginya volume perdagangan produk olahan kayu antara negaranegara tersebut dengan Indonesia.

Dengan mempertimbangkan bahwa PDB per kapita sebeagai variabel utama, tabel 7 menjelaskan signifikansi estimasi untuk Indonesia, Filipina, Singapura, dan Thailand. Namun demikian, tanda notasi PDB untuk setiap negara bernilai negatif. Hal ini menjelaskan bahwa Indonesia dengan negara-negara yang telah disebutkan sebelumnya memiliki hubungan perdagangan yang kuat satu sama lain. Untuk kasus Indonesia dan Singapura, Indonesia mengimpor produk berbasis agro dari Singapura sebesar $4.43 \%$ untuk memenuhi konsumsi domestik. Proporsi Indonesia adalah 3.1\% dari total produk berbasis agro yang diekspor ke Singapura. Produk yang diekspor sebagian besar adalah bahan mentah untuk selanjutnya diproses atau dikonsumsi oleh Singapura.

Selanjutnya, Filipina merupakan negara dengan biaya perdagangan yang paling mahal.Oleh karena itu, produsen Indonesia sebaiknya mengalokasikan dana khusus untuk mengatasi biaya perdagangan terhadap Filipina sebesar 25.68\% dari total transaksi. Tabel 7 juga berisi tentang informasi biaya impor (ACEPT). Namun demikian, tidak satu pun negara menunjukkan estimasi yang signifikan. Dengan demikian, tidak ada lagi analisis yang berkaitan dengan parameter tersebut. Makalah ini juga menemukan signifikansi estimasi nilai tukar IDR terhadap Ringgit Malaysia (RMY). Saat IDR menguat atas RMY, maka neraca perdagangan produk berbasis agro Indonesia dapat mengalami defisit hingga $0.48 \%$. Notasi adjusted $R^{2}$ menyimpulkan bahwa semua negara yang dipilih sebagai mitra dagang Indonesia melakukan transaksi yang begitu besar dalam skema AFTA untuk produk berbasis agro.

Tabel 8 memberikan informasi tentang signifikansi estimasi PDB untuk semua negara anggota kecuali Brunei. Pada kasus Indonesia dan Filipina, dijelaskan bahwa Indonesia memiliki notasi yang negatif sehingga Indonesia diimplikasikan sebagai importir. Hal ini memungkinkan Filipina mengekspor perikanannya ke Indonesia sebesar $4.5 \%$ dari total kapasitas.Yang menariknya adalah terjadi pengehematan dari transaksi perdagangan dengan Brunei, Malaysia, dan Singapura. Hal ini dimungkinkan terjadi oleh aktifnya negara tersebut mengirim kru untuk membeli produk perikanan Indonesia secara langsung di Indonesia.

Dapat disimpulkan bahwa hanya Indonesia dan Thailand yang memiliki estimasi tarif perdagangan yang signifikan. Sebagai tambahan, hasil yang diregresi bertanda negatif menyebabkan tarif Indonesia yang lebih rendah dari Thailand. Maka dari itu, menjadi importir lebih baik bagi Indonesia dan seharusnya menggunakan strategi penciptaan perdagangan untuk menghadapi Thailand. Jadi, produsen Indonesia akan menurunkan tingkat harga produk 
perikanannya hingga 3.5\% agar sama tingkat harganya dengan produk perikanan dari Thailand. Produsen Indonesia bisa mendapatkan surplus karena harga yang lebih rendah dari Thailand, khusus untuk barang mentah dan barang setengah jadi. Konsumen Indonesia memiliki surplus di sektor perikanan hingga 3.5\%, baik dari dalam negeri atau Thailand. Akan tetapi, penerimaan tarif pemerintah Indonesia turun sebesar 3.5\%.

\begin{tabular}{|c|c|c|c|c|c|}
\hline \multicolumn{6}{|c|}{$\begin{array}{l}\text { Tabel } 8 . \\
\text { Persamaan Gravitasi yang telah Dirubah dan telah Diestimasi untuk Sektor Perikanan }\end{array}$} \\
\hline Indonesia to: & Brunei & Malaysia & Filipina & Singapura & Thailand \\
\hline Konstanta & $\begin{array}{c}-54.18927^{*} \\
(0.0000)\end{array}$ & $\begin{array}{c}-32.76588^{*} \\
(0.0027)\end{array}$ & $\begin{array}{c}8.482359 \\
(0.4249)\end{array}$ & $\begin{array}{c}-22.82341^{* *} \\
(0.0633)\end{array}$ & $\begin{array}{c}4.363658 \\
(0.7965)\end{array}$ \\
\hline$Y_{i}$ & $\begin{array}{c}8.462536^{*} \\
(0.0000)\end{array}$ & $\begin{array}{c}-12.14327^{*} \\
(0.0000)\end{array}$ & $\begin{array}{c}-2.911854^{*} \\
(0.0000)\end{array}$ & $\begin{array}{c}-3.033221^{*} \\
(0.0000)\end{array}$ & $\begin{array}{c}-2.538768^{*} \\
(0.0001)\end{array}$ \\
\hline$Y_{j}$ & $\begin{array}{l}-0.955361 \\
(0.4746)\end{array}$ & $\begin{array}{c}17.36504^{*} \\
(0.0000)\end{array}$ & $\begin{array}{c}4.468222^{*} \\
(0.0000)\end{array}$ & $\begin{array}{l}4.960436^{*} \\
(0.0000)\end{array}$ & $\begin{array}{l}4.601110^{*} \\
(0.0000)\end{array}$ \\
\hline$D_{i j}$ & $\begin{array}{c}10.08323^{*} \\
(0.0004)\end{array}$ & $\begin{array}{l}5.443870^{* * *} \\
(0.0365)\end{array}$ & $\begin{array}{l}-2.647054 \\
(0.2969)\end{array}$ & $\begin{array}{l}6.318731^{* *} \\
(0.0469)\end{array}$ & $\begin{array}{l}-2.040497 \\
(0.6337)\end{array}$ \\
\hline$t_{i}$ & $\begin{array}{l}4.591401^{*} \\
(0.0002)\end{array}$ & $\begin{array}{c}-0.890421 \\
(0.5565)\end{array}$ & $\begin{array}{c}-0.269143 \\
(0.8274)\end{array}$ & $\begin{array}{c}-0.899342 \\
(0.4352)\end{array}$ & $\begin{array}{c}-3.535508^{*} \\
(0.0079)\end{array}$ \\
\hline$t_{j}$ & $\begin{array}{c}0.569777 \\
(0.3563)\end{array}$ & $\begin{array}{c}3.424231^{\text {*** }} \\
(0.0273)\end{array}$ & $\begin{array}{c}2.493441^{* *} \\
(0.0494)\end{array}$ & $\begin{array}{c}2.755098^{* *} \\
(0.0226)\end{array}$ & $\begin{array}{c}5.750686^{*} \\
(0.0000)\end{array}$ \\
\hline$e x_{i}$ & $\begin{array}{c}-1.322690^{* *} \\
(0.0426)\end{array}$ & $\begin{array}{c}2.656597^{*} \\
(0.0004)\end{array}$ & $\begin{array}{c}0.506773^{\text {** }} \\
(0.0356)\end{array}$ & $\begin{array}{c}-0.142433 \\
(0.6105)\end{array}$ & $\begin{array}{c}0.620905^{\text {*** }} \\
(0.0717)\end{array}$ \\
\hline$e x_{j}$ & $\begin{array}{c}1.701005^{* *} \\
(0.0356)\end{array}$ & $\begin{array}{c}-3.775544^{*} \\
(0.0001)\end{array}$ & $\begin{array}{c}-0.092481 \\
(0.7265)\end{array}$ & $\begin{array}{c}0.483130 \\
(0.1283)\end{array}$ & $\begin{array}{c}-0.400784 \\
(0.2780)\end{array}$ \\
\hline N. Adj. $R^{2}$ & $\begin{array}{c}63 \\
0.76646\end{array}$ & $\begin{array}{c}63 \\
0.713238\end{array}$ & $\begin{array}{c}63 \\
0.768666\end{array}$ & $\begin{array}{c}63 \\
0.764817\end{array}$ & $\begin{array}{c}63 \\
0.662725\end{array}$ \\
\hline
\end{tabular}

Untuk kasus nilai tukar antara Indonesia dan Malaysia, penguatan IDR terhadap RMY berakibat pada menurunnya ekspor bersih perikanan Indonesia sebesar $1.11 \%$. The adjusted $R^{2}$ menentukan tingkat perdagangan sektor perikanan Indonesia dengan mitra daganganya dalam skema AFTA. Nilai adjusted $R^{2}$ mengimplikasikan bahwa setiap negara yang telah dipilihmenjadi mitra dagang yang penting bagi Indonesia untuk sektor perikanan.

\section{KESIMPULAN}

Secara keseluruhan bukti empiris atas temuan dinamika perdagangan mengindikasikan beberapa hal penting. Tujuan dari arus perdagangan adalah untuk mendatangkan keuntungan yang sebesar-besarnya untuk Indonesia dalam skema AFTA. Keuntungan ini bisa datang dari keunggulan kompetitif dengan menggunakan PDB sebagai proksi faktor tersebut. Sebenarnya, berdasarkan temuan estimasi PDB, Indonesia dapat disimpulkan sebagai negara yang memiliki keunggulan komparatif alami dibandingkan yang lainnya. Sektor-sektor tersebut telah disebutkan 
dalam analisis temuan dan kajian empiris di atas. Selanjutnya, pengaruh faktor tarif perdagangan bebas relevan pada implementasi strategi penciptaan perdagagangan atau pengalihan perdagangan. Dengan menggunakan kedua strategi tersebut, Indonesia dapat menerapkan strategi penciptaan perdagangan pada sektor produk olahan dari karet hanya terhadap Thailand dalam konteks perdagangan bebas.

Untuk produk olahan dari kayu, Indonesia dapat menggunakan strategi penciptaan perdagangan maupun pengalihan perdagangan terhadap Malaysia tergantung mana yang memberikan keuntungan bagi Indonesia. Namun demikian, tidak ada keuntungan yang bisa didapatkan dari perdagangan di sektor berbasis agro. Sekali lagi, Thailand merupakan mitra dagang paling menguntungkan bagi Indonesia di sektor perikanan. Indonesia dapat menerapkan strategi penciptaan perdagangan untuk meningkatkan volume perdagangan dengan Thailand.

Temuan dari adjusted $R^{2}$ menjelaskan dinamika besaran arus perdagangan dengan mitra dagangnya dari ASEAN. Dengan demikian Indonesia diharapkan mampu untuk mendapatkan keuntungan yang lebih banyak atau surplus. Sehingga, untuk sektor produk dari karet, Indonesia sebaiknya lebih fokus untuk mengarahkan arus perdagangannya dengan Thailand dibandingkan yang lain. Untuk produk dari kayu, Brunei adalah pengecualian, akan tetapi yang lainnya tetap strategis untuk Indonesia. Sebagai contoh, Indonesia harus memperluas perdagangannya dengan negara anggota yang telah dipilih pada sektor produk berbasis agro dan perikanan.

Secara keseluruhan, makalah ini menyarankan jika Indonesia ingin menjadi pemain kunci AFTA di masa mendatang, maka Indonesia harus meningkatkan pembanganunan infrastruktur untuk menyokong perdagangan dan kemudian meningkatkan PDB per kapitanya, meminimalisir hambatan dan biaya perdagangan, serta mengendalikan nilai tukar dengan baik. Sehingga keuntungan dapat diraih oleh Indonesia di tahun 2015.

Penelitian selanjutnya di masa mendatang sangat diperlukan untuk mengkaji fasilitas perdagangan Indonesia dalam mempersiapkan AFTA 2015. Mengukur fasilitas perdagangan Indonesia perlu dilakukan saat hambatan perdagangan yang berupa tarif dan non-tarif menurun. Fasilitas perdagangan menggambarkan mudahnya pergerakan barang antar batas wilayah seperti fasilitas infrastruktur, pelabuhan, jasa logistik, dan efisiensi bea cukai. Untuk mengukur fasilitas perdagangan Indonesia, parameter yang dapat digunakan adalah Indeks Kinerja Logistik. Dengan demikian, Indonesia dapat memperoleh keuntungan yang lebih besar dari fasilitas perdagangannya dibandingkan negara anggota lainnya dalam skema perdagangan bebas ASEAN. Contoh parameter lain yang dapat digunakan adalah manufaktur berbasis industri sektoral Indonesia. Hal ini menarik dikarenakan ketersediaan sumber daya alam Indonesia sebagai keunggulan komparatifakan berkurang di masa mendatang. Sehingga di masa mendatang Indonesia seharusnya mengandalkan sektor industri manufaktur untuk menggantikan masalah langkanya ketersediaan sumber daya alam. Di masa mendatang, peneliti yang tertarik untuk menelusuri perdagangan bebas ASEAN 2015 harus dapat melakukan inovasi lebih jauh khususnya tentang Indonesia. 


\section{DAFTAR PUSTAKA}

Aczel, D., Amir, (1995), Statistics Concepts and Applications, Irwin.

ASEAN Economic Community Blueprint. "ASEAN Secretariat", Jakarta, January 2008.

ASEAN Economic Community Chartbook. "ASEAN Secretariat", Jakarta, September 2009.

ASEAN. "ASEAN Free Trade Area (AFTA Council)" Available at http://www.asean.org/ 19585.htm., Accessed on October 2010.

Bali and Indonesia on the Net. Available at http://www.indo.com/distance, Accessed on March 2010.

Balassa, Bela. "Trade Creation and Trade Diversion in the EEC", Economic Journal, No. 77, p121, 1967.

Brada, Josef C dan Mendez, Jose A. "Economic Integration Among Developed, Developing and Centrally Planned Economies: A Comparative Analysis", The Review of Economics and Statistics, 1985.

Calvo-Pardo, Hector., Freund, Caroline., dan Ornelas, Emanuel. "The ASEAN Free Trade Agreement: Impact on Trade Flows and External Trade Barriers". Policy Research Working Paper The World Bank Development Research Group Trade and Integration Team, 2009.

City Distance Tool. Available at http://www.geobytes.com/citydistancetool.htm, Accessed on March 2010.

Dodge, David. "Economic Integration in North America", Bank of Canada Review, p45-50, 2003.

El-Agraa, Ali M, (1997),Economic Integration Worldwide, St Martins Press, New York.

Gujarati, N., Damodar dan Porter, C., Dawn, (2009), Basic Econometrics, Fifth Edition, McGraw-Hill International Edition.

Husted, Steven dan Melvin, Michael, (2010),International Economics, Eight Edition, AddisonWesley.

Indonesian and Bali on the net. Available at http://www.indo.com/distance, accessed on October 2010. 
Krugman, Paul R. dan Maurice Obstfeld, (2009), International Economics: Theory and Policy, Eight Edition, Addison-Wesley.

Market Analysis dan Research, International Trade Center. "Trade Map", Available at http:/ /www.trademap.org/selectionmenu.aspx, Accessed on October 2010.

Pacheco, Amurgo., Alberto and Pierola, Denisse., Martha. "Patterns of Export Diversifcation in Developing Countries: Intensive and Extensive Margins". Policy Research Working Paper, 4473, The World Bank International Trade Department, 2008.

Pelkmans, Jacques, (2006), European Integration: Method and Economic Analysis, Third Edition, Pearson Education Limited.

Tamirisa, T., Natalia. "Exchange and Capital Controls as Barriers to Trade". IMF working paper, 1999.

Venables. J, Anthony. "International Trade; Regional Economic Integration", The International Encyclopedia of Social and Behavioral Sciences, Article 34), London School of Economics, 2000.

Zarzoso, Martines., Inmaculada." Gravity Model: An Application to Trade Between Regional Blocs", Atlantic Economic Journal, 2003. 